\title{
PENGARUH GAYA KEPEMIMPINAN DAN BUDAYA ORGANISASI TERHADAP KINERJA KARYAWAN PADA PT BANK SUMUT KANTOR CABANG SYARIAH PEMATANGSIANTAR
}

\author{
Oleh: \\ Alisha Widiyanti \\ S1 Manajemen \\ Darwin Lie, Marisi Butarbutar, Andy Wijaya
}

Abstraksi

Adapun rumusan masalah penelitian ini adalah bagaimana pengaruh gaya kepemimpinan dan budaya organisasi terhadap kinerja karyawan pada PT Bank Sumut Kantor Cabang Syariah Pematangsiantar. Metode yang digunakan dalam penulisan ini adalah penelitian kepustakaan dan penelitian lapangan. Populasi pada penelitian ini adalah seluruh karyawan PT Bank Sumut Kantor Cabang Syariah Pematangsiantar yang berjumlah 35 orang. Data yang digunakan adalah data dengan cara kualitatif dan data kuatitatif, dan teknik pengumpulan data dengan cara kuesioner, wawancara dan dokumentasi. Kemudian teknik analisa data menggunakan metode deskriptif kualitatif dan metode deskriptif kuantitatif.

Hasil analisa dari regresi linier berganda yaitu $\hat{Y}=7,323+0,518 X_{1}+0,173 X_{2}$, artinya terdapat pengaruh yang positif antara gaya kepemimpinan dan budaya organisasi terhadap kinerja karyawan. Hasil analisis koefisien korelasi diperoleh nilai $r=0,831$, artinya terdapat hubungan yang sangat kuat dan positif antara gaya kepemimpinan dan budaya organisasi dengan kinerja karyawan. Kemudian diperoleh nilai koefisien determinasi $=0,691$, artinya tinggi rendahnya kinerja karyawan dapat dijelaskan oleh gaya kepemimpinan dan budaya organisasi sebesar $69,1 \%$, sedangkan $30,9 \%$ dijelaskan oleh faktor lain yang tidak dibahas dalam penelitian ini. Dari hasil pengolahan dan perhitungan kuesioner penulis mendapatkan kesimpulan bahwa gaya kepemimpinan dan budaya organisasi yang diterapkan PT Bank Sumut Kantor Cabang Syariah Pematangsiantar berpengaruh positif dan signifikan terhadap kinerja karyawan. Hal ini dibuktikan melalui uji hipotesis secara simultan, dimana hasil uji $f_{\text {hitung }}(35,771)>F_{\text {tabel }}(3,29)$ dengan taraf signifikansi $0,000<\alpha 0,05$.

Kata kunci: Gaya Kepemimpinan, Budaya Organisasi, Kinerja Karyawan.

\section{Abstraction}

The formulation of this research problem is how the influence of leadership style and organizational culture to employee performance at PT Bank Sumut Kantor Cabang Syariah Pematangsiantar. The method used in this paper is literature research and field research. Its population is all employees of PT Bank Sumut Kantor Cabang Syariah Pematangsiantar amounting to 35 people. The data used are qualitative and qualitative data, and data collection techniques used are questionnaire method, interview method and documentation method. Then the technique of data analysis using qualitative descriptive method and quantitative descriptive method.

The result of analysis from multiple linear regression is $\hat{Y}=7,323+0,518 X_{1}+0,173 X_{2}$, meaning there is positive influence between leadership style and organizational culture to employee performance. The results of correlation coefficient analysis obtained value $r=0,831$ which means there is a high correlation between leadership style, organizational culture to employee performance. Then obtained the value of coefficient of determination $=0,691$, meaning that high employee performance can be explained by leadership style and organizational culture of $69,1 \%$, while $30,9 \%$ explained by other factors not discussed in this study. From the results of processing and calculation of the questionnaire, the authors get the conclusion that the leadership style and organizational culture applied by PT Bank Sumut Kantor Cabang Syariah Pematangsiantar have a positive and significant impact on employee performance. This is proven by hypothesis testing simultaneously, where the test result $t_{\text {hitung }}(35,771)>t_{\text {tabel }}(3,29)$ with significance level $0,000<\alpha 0,05$

Keywords: Leadership Style, Organizational Culture, Employees Performance.

\section{A. PENDAHULUAN}

\section{A. Latar Belakang Masalah}

Bank Sumut sendiri baru membuka usaha unit syariahnya di tahun 2004 ( \pm 13 Tahun lalu), dan diresmikan oleh Direktur Utama Bapak Gus Irawan. Di Kota Pematangsiantar Bank Sumut Cabang Syariah mulai berdiri pada tanggal 30
Desember 2011 yang terletak di Jl. Jend. Sudirman Blok A No. 5-6 Pematangsiantar. Bank Sumut Cabang Syariah Pematangsiantar ini sendiri mulai beroperasi pada awal Tahun 2012. Sebagai Kepala Pimpinan Cabang pertama yaitu Bapak Haznul Harahap, namun 
saat ini telah digantikan oleh Bapak Ahmad Mursalin Lubis.

Kinerja karyawan secara umum dapat dipahami sebagai besarnya kontribusi yang diberikan karyawan terhadap kemajuan dan perkembangan bagi perusahaan, kinerja perusahaan akan dirasakan puas apabila target kerja berjalan dengan baik dan efisien, kienrja karyawan harus disokong oleh prestasi kerja dan perilaku kerja guna untuk mencapai kinerja yang lebih baik.

Salah satu faktor yang berpengaruh terhadap kinerja karyawan adalah gaya kepemimpinan. Gaya kepemimpinan yang diterapkan pada PT Bank Sumut Kantor Cabang Syariah Pematangsiantar adalah gaya otokratis, gaya demokratis, dan gaya bebas kendali (laissez-faire). Gaya otokratis yang diterapkan pada PT Bank Sumut Kantor Cabang Syariah Pematangsiantar yaitu menggunakan gaya seperti pimpinan yang memusatkan pada wewenang, lalu gaya demokratis sebagai pemberi keputusan pada karyawan, dan gaya bebas kendali (laissezfaire) sebagai pemberi kebebasan penuh pada karyawan.

Selain gaya kepemimpinan, budaya organisasi juga dapat mempengaruhi kinerja karyawan. Budaya organisasi yang diterapkan oleh PT Bank Sumut Kantor Cabang Syariah Pematangsiantar meliputi aturan perilaku yang diamati, norma, nilai dominan, filosofi, aturan, dan iklim organisasi.

\section{Rumusan Masalah}

a. Bagaimana gambaran gaya kepemimpinan, budaya organisasi dan kinerja karyawan Pada PT Bank Sumut Kantor Cabang Syariah Pematangsiantar.

b. Bagaimana pengaruh gaya kepemimpinan dan budaya organisasi terhadap kinerja karyawan Pada PT Bank Sumut Kantor Cabang Syariah Pematangsiantar baik secara simultan maupun parsial.

\section{Tujuan Penelitian}

a. Untuk mengetahui gambaran gaya kepemimpinan, budaya organisasi, dan kinerja karyawan Pada PT Bank Sumut Kantor Cabang Syariah Pematangsiantar.

b. Untuk mengetahui pengaruh gaya kepemimpinan dan budaya organisasi terhadap kinerja karyawan Pada PT Bank Sumut Kantor Cabang Syariah Pematangsiantar baik secara simultan maupun parsial.

\section{Metode Penelitian}

Yang menjadi objek penelitian dalam hal ini adalah Karyawan PT Bank Sumut Kantor Cabang Syariah Pematangsiantar. Yang terletak di Jalan Jenderal Sudirman Blok A No.
5-6 Kelurahan Proklamasi, Kecamatan Siantar Barat Kota Pematangsiantar. Pada penelitian ini yang menjadi populasi adalah seluruh karyawan yang terdapat pada PT Bank Sumut Kantor Cabang Syariah Pematangsiantar yang berjumlah 35 orang. Seluruh karyawan yang berjumlah 35 orang akan menjadi sampel sebagai responden untuk menjawab kuesioner yang penulis sebarkan, mengingat jumlahnya yang kurang dari 100 orang dan ketersediaan waktu penulis serta untuk keakuratan hasil penelitian.

Adapun Desain penelitian yang digunakan dalam penulisan skripsi ini adalah Penelitian Kepustakaan (Library Research) dan Penelitian Lapangan (Field Research). Teknik pengumpulan data yang dilakukan penulis dalam penelitian ini adalah berupa Kuesioner, Wawancara dan Dokumentasi. Adapun jenis data yang digunakan dalam penelitian ini adalah jenis data kualitatif dan data kuantitatif. Hasil data yang diperoleh dari lapangan akan dianalisis secara deskriptif baik bersifat kualitatif dan kuantitatif.

\section{B. LANDASAN TEORI}

\section{Manajemen}

Menurut Handoko (2003:8), manajemen adalah suatu proses perencanaan, pengorganisasian, pengarahan dan pengendalian serta pegawasan kegiatan organisasi dan penggunaan sumber daya manusia lainnya agar tercapai tujuan organisasi. Menurut Daft (2002:8), manajemen adalah pencapaian tujuan organsasi dengan cara yang efektif melalui perencanaan, pengorganisasian, pengarahan dan pengendalian sumber daya organisasi. Sedangkan menurut Griffin (2004:7), manajemen adalah suatu rangkaian aktivitas (termasuk perencanaan dan pengembalian keputusan, pengorganisasian, kepemimpinan dan pengendalian) yang diarahkan pada sumber-sumber daya organisasi (manusia, financial, fisik dan informasi) untuk mencapai tujuan organisasi dengan cara yang efektif dan efisien.

Berdasarkan definisi para ahli, disimpulkan bahwa manajemen adalah suatu proses perencanaan, pengorganisasian, pengambilan keputusan, pengendalian dan pengarahan pada sumber-sumber daya organisasi untuk mencapai tujuan perusahaan secara efektif dan efisisen.

\section{Manajemen Sumber Daya Manusia}

Menurut Mathis dan John (2006:3), manajemen sumber daya manusia adalah rancangan sistem-sistem formal dalam sebuah organisasi untuk memastikan penggunaan, bakat manusia secara efektif dan efisian guna mencapai tujuan organisasional. Menurut Mondy (2008:4), manajemen sumber daya 
manusia adalah pemanfaatan sejumlah individu untuk mencapai tujuan-tujuan orgnisasi. Sedangkan menurut Zainal (2015:4), manajemen sumber daya manusia merupakan salah satu bidang dari manajemen umum yang meliputi segi-segi perencanaan, pengorganisasian, pelaksanaan dan pengendalian.

Berdasarkan pendapat para ahli di atas, maka penulis menyimpulkan bahwa manajemen sumber daya manusia adalah manusia yang merancang sistem-sistem formal berupa proses perencanaan, pengorganisasian, penyusunan staf, pemberian kompensasi dan pengintegrasian untu mencapai tujuan organisasi.

\section{Gaya Kepemimpinan}

Menurut Luthans (2006:680), gaya kepemimpinan adalah gaya yang digunakan oleh manajer atau penyelia pada manajemen sumber daya manusia. Menurut Thoha (2003:303), gaya kepemimpinan adalah suatu norma perilaku yang digunakan oleh seorang pada saat orang tersebut mencoba mempengaruhi perilaku orang lain seperti yang ia lihat. Rivai dan Mulyadi (2012:42), mengemukakan gaya kepemimpinan adalah alat menyeluruh dari tindakan seorang pemimpin, baik yang tampak maupun yang tidak tampak oleh bawahannya, artinya gaya kepemimpinan adalah perilaku yang strategis, sebagai hasil kombinasi dari falsafah, keterampilan, sifat, sikap yang sering diterapkan oleh seorang pemimpin ketika ia mencoba mempengaruhi kinerja bawahannya.

Dari berbagai pendapat di atas disimpulkan bahwa gaya kepemimpinan adalah sekumpulan ciri yang digunakan oelh pemimpin untuk mempengaruhi bawahannya untuk mencapai tujuan organisasi.

Menurut Handoko (2004:155), ada tiga tipe gaya kepemimpinan yaitu otokratis, demokratis, dan laissez-faire.

a. Gaya kepemimpinan otokratis, gaya otokratis adalah kemampuan mempengaruhi orang lain agar bersedia bekerjasama untuk mencapai tujuan yang telah ditentukan dengan cara segala kegiatan yangakan dilakukan dipusatkan oleh pimpinan semata-mata.

b. Gaya Kepemimpinan demokratis, gaya demokratis adalah kemampuan mempengaruhi orang lain agar bersedia bekerjasama untuk mencapai tujuan yang telah ditetapkan dengan berbagai kegiatan yang dilakukan ditentukan bersama antara pemimpin dan bawahan.

c. Laissez-Faire, gaya laissez-faire adalah kemampuan mempengaruhi orang lain agar bersedia bekerjasama untuk mencapai tujuan yang telah ditetapkan dengan cara berbagai kegiatan yang akan dilakukan lebih banyak diserahkan kepada bawahan.

\section{Budaya Organisasi}

Menurut Griffin (2004:162), budaya organisasi (organization culture) adalah serangkaian nilai, keyakinan, perilaku, kebiasaan, dan sikap yang membantu seorang anggota organisasi dalam memahami prinsipprinsip yang dianut oleh organisasi tersebut, bagaimana organisai tersebut melakukan segala sesuatu, dan apa yang dianggapnya penting. Menurut Robbins dan Mary (2010:63), budaya organisasi (organization culture) telah diketengahkan sebagai nilai-nilai, prinsipprinsip, tradisi, dan cara-cara bekerja yang dianut bersama oleh para anggota organisasidan mempengaruhi cara mereka bertindak. Sedangkan menurut Kreitner (2014:62), budaya organisasi (organization culture) adalah perangkat asumsi yang dibagi dan diterima secara implisit begitu saja serta dipegang oleh satu kelompok yang menentukan bagaimana hal itu dirasakan, dipikirkan, dan bereaksi terhadap lingkungan yang beragam.

Berdasarkan beberapa pendapat para ahli di atas, penulis menyimpulkan budaya organisasi merupakan suatu kekuatan sosial yang tidak tampak berupa nilai-nilai dan sistem yang dapat menggerakkan orang-orang dalam suatu organisasi untuk melakukan pekerjaannya demi mencapai tujuan organisasi. Budaya organisasi yang kuat akan mendukung tujuan-tujuan organisasi, sebaliknya budaya yang lemah atau negatif dapat menghambat tercapainya tujuan organisasi.

Menurut Luthans (2006:125), budaya organisasi mempunyai sejumlah karakteristik, beberapa diantaranya:

a. Aturan perilaku yang diamati. Ketika anggota organisasi berinteraksi satu sama lain, mereka menggunakan bahasa, istilah, ritual umum yang berkaitan dengan rasa hormat dan cara berperilaku.

b. Norma. Ada standar perilaku, mencakup pedoman mengenai seberapa banyak pekerjaan yang dilakukan, yang dalam banyak perusahaan menjadi "jangan melakukan terlalu banyak jangan terlalu sedikit".

c. Nilai dominan. Organisasi mendukung dan berharap peserta membagikan nilai-nilai utama. Contoh khususnya adalah kualitas produk tinggi, sedikit absen, efesiensi tinggi.

d. Filosofi. Terdapat kebijakan yang membentuk kepercayaan organisasi mengenai bagaimana atau pelanggan diperlakukan.

e. Aturan. Terdapat pedoman ketat berkaitan dengan pencapaian perusahaan. Pendatang baru harus mempelajari teknik dan prosedur 
yang ada agar diterima sebagai anggota kelompok yang berkembang.

f. Iklim organisasi. Ini merupakan keseluruhan "perasaan" yang disampaikan dengan pengaturan yang bersifat fisik, cara peserta berinteraksi dan cara anggota organisasi berhubungan dengan pelanggan dan individu dari luar.

\section{Kinerja Karyawan}

Menurut Zainal (2015:447), kinerja adalah suatu tampilan keadaan secara utuh atas perusahaan selama periode waktu tertentu, merupakan hasil atau prestasi yang dipengaruhi oleh kegiatan operasional perusahaan dalam memanfaatkan sumbersumber daya yang dimiliki. Menurut Sutrisno (2010:171), kinerja karyawan adalah prestasi yang diperoleh seseorang dalam melakukan tugas. Sedangkan menurut Bangun (2012:231), kinerja (performance) adalah hasil pekerjaan yang dicapai sesorang berdasarkan persyaratan-persaratan pekerjaan (job requirement).

Berdasarkan beberapa pendapat ahli di atas, kinerja merupakan hasil usaha seseorang yang memiliki kemampuan dan perbuatan dalam situasi tertentu dalam melaksanakan tugas dan tanggung jawab yang diberikan kepadanya. Baik buruknya kinerja seseorang dapat mempengaruhi keberhasilan perusahaan. Menurut Surat Edaran Bank Indonesia No.15/4. INTERN tanggal 26 Februari 2013, kinerja pegawai dapat dilihat dari:

a. Prestasi kerja adalah tingkat pencapaian tugas pokok dan tugas tambahan pegawai pada suatu periode penilaian.

b. Perilaku kerja adalah tingkat antara sikap kerja pegawai dalam melaksanakan tugas dibandingkan dengan kompetensi inti pegawai. Bank Indonesia dan tingkat kehadiran sebagaimana yang diisyaratkan dalam satu periode penilaian.

\section{Pengaruh Gaya Kepemimpinan dan Budaya Organisasi Terhadap Kinerja Karyawan}

Gaya kepemimpinan dan kinerja karyawan merupakan suatu komponen yang berpengaruh dalam meningkatkan kinerja. Menurut Luthans (2006:680), menyatakan jika gaya kepemimpinan yang digunakan oleh manajer atau penyelia pada manajemen sumber daya manusia ini, Dengan gaya kepemimpinan yang tepat maka para karyawan akan merasa puas dan termotivasi untuk melaksanakan tugasnya dengan penuh tanggung jawab yang dimiliki akan berdampak pada peningkatan kinerjanya.

Untuk dapat mengetahui pengaruh budaya organisasi dengan kinerja karyawan, maka Luthans (2006:125), menyatakan bahwa organisasi mengarahkan perilaku anggota organisasi yang dapat mempengaruhi kinerja anggota organisasi tersebut. Dengan adanya budaya organisasi akan memudahkan anggota organisasi untuk mengetahui tindakan apa yang seharusnya dilakukan sesuai dengan yang diharapkan organisasi. Maka dari itu perlunya membangun budaya organisasi yang baik sehingga dapat diterapkan para karyawan dan dengan adanya budaya tersebut dapat meningkatkan kinerjanya.

Maka dapat disimpulkan bahwa gaya kepemimpinan dan budaya organisasi memiliki pengaruh yang berdampak pada peningkatan kinerja karyawan. Penerapan gaya kepemimpinan yang efektif, yaitu dapat menyesuaikan gaya kepemimpinan dengan situasi dan kondisi yang ada serta penerapan budaya organisasi yang baik serta terkoordinasi akan motivasi para karyawan untuk bekerja dengan baik dan meningkatkan kinerjanya.

\section{PEMBAHASAN}

1. Analisis

a. Deskriptif Kualitatif

Analisis deskriptif dimaksudkan untuk mendapatkan gambaran atau deskripsi mengenai tanggapan dari karyawan mengenai Pengaruh gaya kepemimpinan dan budaya organisasi terhadap kinerja karyawan pada PT Bank Sumut Kantor Cabang Syariah Pematangsiantar. Setelah pengujian data, maka langkah selanjutnya adalah peneliti melakukan pengkajian analisis kualitatif sebagai gambaran fenomena dari variabel penelitian pada saat sekarang ini. Adapun penetapan kriteria nilai data-data jawaban dari responden tersebut dimasukkan ke dalam kelas-kelas interval, dimana penentuan intervalnya menggunakan rumus sebagai berikut:

Interval kelas $=\frac{\text { Nilai Tertinggi }- \text { Nilai Terendah }}{\text { (j) }}$

$=\frac{5-1}{5}$

$=\frac{4}{5}$

$=0,8$

Dari rumus di atas, diperoleh nilai interval kelas $=0,8$, sehingga berlaku ketentuan kategori dengan hasil sebagai berikut:

\section{Tabel 1}

Nilai Interval dan Kategori Jawaban Responden.

\begin{tabular}{|c|c|}
\hline Nilai Interval & Kategori \\
\hline $1,00-1,80$ & $\begin{array}{c}\text { Sangat Tidak Baik (STB) / Sangat } \\
\text { Lemah (SL) }\end{array}$ \\
\hline $1,81-2,60$ & Tidak Baik (TB) / Lemah (L) \\
\hline $2,61-3,40$ & $\begin{array}{c}\text { Cukup Baik (CB) / Cukup Kuat } \\
(\mathrm{CK})\end{array}$ \\
\hline $3,41-4,20$ & Baik (B) / Kuat (K) \\
\hline $4,21-5,00$ & $\begin{array}{c}\text { Sangat Baik (SB) / Sangat Kuat } \\
(\mathrm{SK})\end{array}$ \\
\hline
\end{tabular}

Sumber: Data diolah 


\section{Gambaran Gaya Kepemimpinan pada PT Bank Sumut Kantor Cabang Syariah Pematangsiantar}

Gaya kepemimpinan merupakan sikap, sifat, dan karakter yang terwujud dalam tingkah laku yang melekat dalam diri seorang pemimpin pada saat mengarahkan dan mempengaruhi bawahannya. Gaya kepemimpinan yang diterapkan oleh manajer area sangat berpengaruh terhadap kepuasan kerja karyawan. Gaya kepemimpinan yang dapat dimengerti setiap kemampuan dan karakter para karyawan akan membuat para karyawan merasa lebih dihargai dan lebih nyaman dalam melaksanakan pekerjaannya.

Gaya kepemimpinan yang diterapkan oleh manajer area antara lain gaya otokratis, demokrasi serta laissez faire. Manajer area menggunakan gaya otokratis pada saa penentuan kebijaksanaan, para karyawan berani bertindak dan mengambil keputusan atas persetujuan manajer. Hal lain juga dapat dilihat pada saat terjadinya pelanggaran terhadap tata tertib yang berlaku, manajer langsung memberikan peringatan. Gaya demokratis digunakan pada saat adanya rapat dengan mellibatkan para karyawan dalam pengambilan keputusan serta mau menghargai saran dan ide yang diajukan oleh karyawan. Hal lain dapat dilihat pada saaat berinteraksi dengan para karyawan. Sehingga masih adanya sebagian karyawan kurang bertanggung jawab dalam melaksanakan tugasnya. Gaya laissez faire ditunjukkan pada saat karyawan melaksanakan tugasnya. Dimana manajer tidak berpartisipasi ketika karyawan menjalankan pekerjaannya misalnya dalam penggunaan metode.

Berdasarkan hasil analisis deskriptif kualitatif mengenai gaya kepemimpinan dari segi gaya otokratis, gaya demokratis, laissezfaire memiliki rata-rata jawaban keseluruhan 3,78 yang berkriteria jawaban baik. Nilai jawaban responden tertinggi ada pada dimens gaya kepemimpinan otokratis untuk indikator pembatasan partisipasi karyawan bernilai 4,14 berkriteria jawaban baik dan nilai jawaban responden terendah berada pada dimensi gaya kepemimpinan otokratis untuk indikator metode kerja yang didikte pimpinan bernilai 3,17 dengan kriteria jawaban cukup baik.

\section{Gambaran Budaya Organisasi pada PT Bank Sumut Kantor Cabang Syariah Pematangsiantar}

Budaya organisasi merupakan nilai-nila yang dipahami dengan baik oleh anggota organisasi sebagai kebiasaan yang membedakannya dengan organisasi lain. Budaya organisasi harus dijunjung tinggi anggota organisasi agar mampu mencapai tujuan organisasi itu sendiri.pada PT Bank Sumut Kantor Cabang Syariah Pematangsiantar budaya organisasi yang diterapkan berupa aturan perilaku yang diamati, norma-norma, nilai dominan, filosofi, aturan, dan ikllim organisasi. Aturan perilaku, yaitu aturan ketika anggota organisasi berinteraksi satu sama lain menggunakan bahasa dan ritual umum seperti penggunaan bahasa indonesia di lingkungan perusahaan dan doa bersama yang dilakukan sebelum memulai pekerjaan. Norma yaitu standar perilaku yang mencakup seberapa banyak pekerjaan yang dilakukan dimana pegawai mengerjakan pekerjaan yang telah diperintahkan dengan baik.

Nilai dominan artinya nilai-nilai utama yang didukung dan diharapkan organisasi mampu untuk dibagikan anggota organisasi seperti mengerjakan pekerjaan dengan tepat waktu dan memiliki absen yang sedikit dalam bekerja. Filosofi yaitu kebijakan yang membentuk kepercayaan organisasi bagaimana karyawan dan atau nasabah diperlakukan di PT Bank Sumut Kantor Cabang Syariah Pematangsiantar. Aturan ialah pedoman yang berkaitan dengan pecapaian organisasi seperti aturan larangan menerima suap dan gratifikasi pada PT Bank Sumut Kantor Cabang Syariah Pematangsiantar. Iklim organisasi, yaitu pengaturan yang bersifat fisik seperti cara peserta berinteraksi dan berhubungan dengan pelanggan dan individu dimana pegawai bersikap ramah dan sopan santun kepada sesama karyawan ataupun nasabah.

Berdasarkan hasil analisis deskriptif kualitatif mengenai budaya organisasi dari segi aturan perilaku yang diamati, norma, nilai dominan, filosofi, aturan, dan iklim organisasi memiliki rata-rata jawaban keseluruhan 3,64 dengan kriteria jawaban kuat. Nilai rata-rata yang tertinggi sebesar 3,94 dengan kriteria jawaban kuat berada pada dimensi nilai dominan untuk indikator standar efisiensi kinerja

Sedangkan nilai rata-rata terendah sebesar 3,31 dengan kriteria jawaban cukup kuat berada pada dimensi aturan untuk indikator pemberlakuan sanksi saat melanggar tata tertib perusahaan.

\section{Gambaran Kinerja Karyawan pada PT} Bank Sumut Kantor Cabang Syariah Pematangsiantar

Kinerja merupakan suatu kejadian keadaan yang harus diketahui mengenai tingkatpencapaian suatu perusahaan yang dihubungkan dengan visi perusahaan. Kinerja karyawan pada PT Bank Sumut Kantor Cabang Syariah Pematangsiantar diukur melalui penilaian atas hasil kerja yangtelah dicapai, dan biasanya disampaikan pada briefieng pagi setiap rabu dan jumat atau pada rapat tertentu sebagai sarana pertukan pendapat maupun menyampaikan keluhan yang dirasakan.

Kinerja karyawan yang dilaksanakan PT Bank Sumut Kantor Cabang Syariah Pematangsiantar diukur oleh dimensi 
keberhasilan yang dicapai. Hal yang berkaitan dengan keberhasilan adalah kemampuan pegawai menguasai setiap pekerjaan dan memiliki inovasi dalam bekerja. Dimensi tanggung jawab dilaksanakan untuk melihat sejauh mana pegawai mampu mempertanggungjawabkan hasil dari pekerjaan yang dilkukan. Dimensi pencapaian target merupakan hasil yang dicapai untuk mengetahui tinggi rendahnya hasil kinerja karyawan dibandingkan dengan target yang ditetapkan.

Dimensi tugas yaitu seberapa baik dan tepat waktu dalam menyelesaikan tugas. Dimensi pengembangan diri berkaitan dengan kemamuan karyawan untuk belajardengan memanfaatkan kesempatan belajar yang ada Dimensi integritas yaitu ketaatan karyawan dalam mengikuti peraturan perusahaan.

Dari total jawaban responden mengenai dimensi prestasi kerja dan perilaku kerja mendapat nilai rata-rata sebesar 3,63 dengan kriteria jawaban baik. Kemudian nilai rata-rata tertinggi sebesar 4,08 dengan kriteria jawaban baik berada pada dimensi perilaku kerja untuk indikator kemampuan anda bekerja secara optimal sepanjang jam kerja. Sedangkan nilai rata-rata terendah sebesar 3,11 dengan kriteria jawaban cukup baik berada pada dimensi prestasi kerja untuk indikator tanggung jawab.

\section{b. Deskriptif Kuantitatif}

\section{1) Analisa Regresi Linear Berganda}

Fungsi dari analisis regresi linear berganda adalah untuk melihat pengaruh yang terjadi di antara ketiga variabel. Selain itu analisis regresi linear juga berfungsi sebagai petunjuk arah hubungan yang terjadi antara variabel dependen dan variabel independen. Untuk melihat apakah ada pengaruh gaya kepemimpinan dan budaya organisasi terhadap kinerja karyawan pada PT Bank Sumut Kantor Cabang Syariah Pematangsiantar digunakan analisis regresi linear berganda.

Tabel 2

Analisis Regresi Linier Berganda Coefficients

\begin{tabular}{|l|c|c|c|}
\hline \multirow{2}{*}{ Model } & \multicolumn{2}{|c|}{$\begin{array}{c}\text { Unstandardized } \\
\text { Coefficients }\end{array}$} & $\begin{array}{c}\text { Standardize } \\
\text { Coefficients }\end{array}$ \\
\cline { 2 - 4 } & $\boldsymbol{B}$ & Std. Error & Beta \\
\hline 1 (Constant) & $\mathbf{7 , 3 2 3}$ & $\mathbf{3 , 4 5 0}$ & \\
Gaya Kepemimpinan & $\mathbf{, 5 1 8}$ & $\mathbf{1 4 0}$ & $\mathbf{, 5 2 4}$ \\
Budaya Organisasi & $\mathbf{, 1 7 3}$ & $\mathbf{0 6 6}$ &, $\mathbf{3 7 0}$ \\
\hline
\end{tabular}

a. Dependent Variabel: Kinerja Karyawan

Sumber: hasil pengolahan data menggunakan spss versi 21 (2017).

Berdasarkan hasil pengolahan data pada tabel 2 di atas, diperoleh model persamaan $\hat{Y}=$ $7,323+0,518 X_{1}+0,173$, artinya terdapat pengaruh positif antara gaya kepemimpinan $\left(X_{1}\right)$ dan budaya organisasi $\left(X_{2}\right)$ terhadap kinerja karyawan (Y) pada PT Bank Sumut Kantor Cabang Syariah Pematangsiantar.

\section{2) Korelasi dan Koefisien Determinasi}

Untuk menghitung kekuatan hubungan kualitas pelayanan, harga dan keputusan pembelian pelanggan, dilakukan melalui analisis korelasi dan koefisien determinasi dengan rumus sebagai berikut:

Tabel 3

Korelasi dan Koefisien Determinasi

Model Summary

\begin{tabular}{|l|r|r|r|r|}
\hline Model & $\mathbf{R}$ & $\begin{array}{r}\boldsymbol{R} \\
\text { Square }\end{array}$ & $\begin{array}{c}\text { Adjusted } R \\
\text { Square }\end{array}$ & $\begin{array}{c}\text { Std. Error of the } \\
\text { Estimate }\end{array}$ \\
\hline 1 & $\begin{array}{r}, 831 \\
\mathrm{a}\end{array}$ &, 691 &, 672 & 2,328 \\
\hline
\end{tabular}

b. Dependent Variabel: Kinerja Karyawan

Sumber: hasil pengolahan data menggunakan spss versi 21 (2017).

Dari hasil korelasi pada tabel 3 di atas diperoleh nilai $r=0,831$ yang artinya terdapat hubungan yang sangat kuat dan positif antara gaya kepemimpinan, budaya organisasi dengan kinerja karyawan pada PT Bank Sumut Kantor Cabang Syariah Pematangsiantar, sesuai dengan kriteria korelasi pada tabel 5 .

Kemudian diperoleh nilai koefisien determinasi $R=0,691$, artinya tinggi rendahnya kinerja karyawan (Y) pada PT Bank Sumut Kantor Cabang Syariah Pematangsiantar sebesar $69,1 \%$ dapat dijelaskan oleh gaya kepemimpinan $\left(X_{1}\right)$ dan budaya organisaasi $\left(X_{2}\right)$ sedangkan sisanya sebesar $30,9 \%$ dipengaruhi oleh faktor lain seperti kompetensi karyawan, pengembangan karir, kompensasi, kepuasan kerja, kemampuan intelektual dan variabel lain yang tidak diteliti dalam penelitian ini.

\section{3) Uji Hipotesis}

\section{a) Uji Simultan (Uji F)}

Uji F digunakan untuk mengetahui apakah variabel bebas (motivasi dan komitmen karyawan) berpengaruh terhadap variabel terikat (kinerja karyawan) secara bersamasama atau simultan. Yaitu dilakukan untuk menentukan diterima atau ditolaknya hipotesis. Jika tingkat signifikan dibawah $5 \%$ atau $\mathrm{F}_{\text {hitung }}>$ $\mathrm{F}_{\text {tabel }}$ maka $\mathrm{H}_{0}$ ditolak.

Tabel 4

Perkiraan Nilai $\boldsymbol{F}_{\text {hitung }}$

$$
\text { Anova }
$$

\begin{tabular}{|c|c|c|c|c|c|}
\hline Model & $\begin{array}{l}\text { Sum of } \\
\text { Squares }\end{array}$ & df & $\begin{array}{c}\text { Mean } \\
\text { Square }\end{array}$ & $F$ & Sig. \\
\hline Regression & 387,721 & 2 & 193,860 & 35,771 & $.000^{\circ}$ \\
\hline Residual & 173,422 & 32 & 5,419 & & \\
\hline Total & 561,143 & 34 & & & \\
\hline
\end{tabular}


a. Dependent Variabel: Kinerja Karyawan

b. Predictors: (Constant), Budaya Organisasi, Gaya Kepemimpinan

Sumber: hasil perhitungan dengan SPSS versi 21 (2017).

Berdasarkan tabel 4 diatas diperoleh nilai $F_{\text {hitung }}$ sebesar $35,771>F_{\text {tabel }}$ dengan $(0,05 ; 2$ vs 32) sebesar 3,29, atau dengan signifikan 0,000 $<\alpha$ 0,05, maka $\mathrm{H}_{0}$ ditolak, artinya gaya kepemimpinan dan budaya organisasi berpengaruh positif dan signifikan terhadap kinerja karyawan pada PT Bank Sumut Kantor Cabang Syariah Pematangsiantar.

\section{b) Uji Parsial (Uji t)}

Untuk menghasilkan suatu kesimpulan yang valid, maka harus dilakukan uji hipotesis. Pengujian ini dilakukan untuk menentukan diterima atau ditolaknya hipotesis, pengujian hipotesis dilakukan untuk mengetahui apakah variabel motivasi dan komitmen karyawan berpengaruh terhadap kinerja karyawan, jika tingkat signifikan dibawa $5 \%$ atau $t_{\text {hitung }}>t_{\text {tabel }}$ maka $\mathrm{H}_{0}$ ditolak.

Tabel 5

Perkiraan Nilai $t_{\text {hitung }}$ Coefficients

\begin{tabular}{|ll|c|c|}
\hline \multicolumn{2}{|c|}{ Model } & $\mathbf{T}$ & Sig. \\
\hline 1 (Constant) & 2,123 &, 042 \\
Gaya Kepemimpinan & $\mathbf{3 , 7 0 4}$ & $\mathbf{, 0 0 1}$ \\
Budaya Organisasi & $\mathbf{2 , 6 1 2}$ & $\mathbf{0 1 4}$ \\
\hline
\end{tabular}

a. Dependent Variabel: Kinerja Karyawan

Sumber: hasil perhitungan dengan SPSS versi 21 (2017).

Berdasarkan tabel 5 di atas, diperoleh nilai $t_{\text {hitung }}$ pada variabel $X_{1}$ (gaya kepemimpinan) sebesar 3,704 > $t_{\text {tabel }}$ dengan $d f=n-k-1$ (35-2 $1=32$ ) sebesar 2,036 atau taraf signifikan 0,001 $<\alpha 0,05$, maka $\mathrm{H}_{0}$ ditolak, artinya gaya kepemimpinan berpengaruh positif dan signifikan terhadap kinerja karyawan pada PT Bank Sumut Kantor Cabang Syariah Pematangsiantar.

Kemudian nilai $t_{\text {hitung }}$ pada variabel $X_{2}$ (budaya organisasi) sebesar 2,612 > dari $t_{\text {tabe }}$ dengan $\mathrm{df}=\mathrm{n}-\mathrm{k}-1$, $(35-2-1=32)$ sebesar 2,036 atau taraf signifikan 0,014 $<\alpha 0,05$, maka $\mathrm{H}_{0}$ ditolak, artinya budaya organisasi berpengaruh positif dan signifikan terhadap kinerja karyawan pada PT Bank Sumut Kantor Cabang Syariah Pematangsiantar.

\section{Evaluasi}

\section{a. Gaya Kepemimpinan pada PT Bank Sumut Kantor Cabang Syariah Pematangsiantar}

Gaya kepemimpinan yang baik adalah gaya yang dapat disesuaikan dengan situasi dan kondisi yang sedang terjadi, mengerti akan sifat, karakter dan kemampuan setiap bawahan.
Gaya kepemimpinan yang diterapkan oleh PT Bank Sumut Kantor Cabang Syariah Pematangsiantar yaitu gaya kepemimpinan otokratis, demokrasi dan bebas kendali (laissez faire). Gaya kepemimpinan tersebut dapat digunakan pada situasi dan kondisi yang berbeda-beda.

Dari rekapitulasi jawaban responden mengenai penerapan gaya kepemimpinan pada PT Bank Sumut Kantor Cabang Syariah Pematangsiantar dapat dilihat bahwa gaya kepemimpinan yang diterapkan pimpinan berada pada nilai rata-rata 3,78 dengan kriteria jawaban baik. Namun masih terdapat beberapa indikator yang walaupun dinilai baik, tetapi masih berada di bawah nilai rata-rata yaitu pada dimensi gaya kepemimpinan otokratis dengan indikator teknik maupun langkah-langkah metode kerja yang didikte oleh pimpinan berada pada nilai rata-rata 3,17 dengan kriteria jawaban cukup baik. Untuk mengatasinya pimpinan/ manajer kiranya melakukan pendekatan dengan karyawan agar metode yang disampaikan diterima baik oleh karyawan dan metode tersebut berhasil dilaksanakan dengan baik oleh karyawan.

Pada dimensi gaya kepemimpinan demokratis dengan indikator pendelegasian memberikan kesempatan kepada karyawannya dalam membuat keputusan berada pada nilai rata-rata 3,71 dengan kriteria jawaban baik. Untuk lebih meningkatkannya manajer terus berusaha membangun komunikasi yang baik dengan karyawan agar lebih selektif dalam pengambiilan keputusan.

Berdasarkan hal-hal di atas, pimpinan/ manajer kiranya harus mampu menyesuaikan gaya kepemimpinannya dengan situasi, kondisi, sifat, serta kemampuan para karyawannya. Dimana pimpinan/ manajer mampu menggunakan gaya kepemimpinannya dengan tepat pada suatu situasi atau kondisi tertentu. Dengan demikian para karyawan akan menjalankan tugasnya dengan baik dan penuh tanggung jawab.

\section{b. Budaya Organisasi pada PT Bank Sumut} Kantor Cabang Syariah Pematangsiantar

Budaya organisasi adalah sebuah sistem yang bermakna yang dianut oleh para karyawan yang membedakan suatu perusahaan dari perusahaan-perusahaan lainnya. Sistem makna bersama ini adalah sekumpulan karakteristik kunci yang dijunjung tinggi oleh perusahaan khususnya pada PT Bank Sumut Kantor Cabang Syariah Pematangsiantar. Dimensi budaya organisasi pada kantor PT Bank Sumut Kantor Cabang Syariah Pematangsiantar dikatakan baik, karena dapat dilihat dari hasil kuesioner yang dibagikan ke responden, secara keseluruhan dengan nilai rata-rata 3,64 dengan kriteria jawaban kuat. 
Dari nilai rata-rata di atas, ada beberapa dimensi budaya organisasi pada kantor PT Bank Sumut Kantor Cabang Syariah Pematangsiantar yang harus menjadi perhatian. Dari perhitungan rata-rata budaya organisasi diperoleh nilai kuat namun ada beberapa aspek dinilai kuat tetapi nilainya masih di bawah ratarata dari indikator-indikator lain, yang pertama dimensi aturan perilaku yang diamati pada keaktifan karyawan dalam mengikuti acaraacara ritual pada nilai rata-rata 3,57 dengan kriteria jawaban kuat, hal ini dapat ditingkatkan lagi dengan cara yaitu membuat acara tersebut dilaksanakan pada hari libur bukan pada hari bekerja sehingga semakin bagusnya keaktifan karyawan dalam mengikuti acara-acara penting di perusahaan

Untuk dimensi norma dengan indikator standar perilaku karyawan dalam bekerja berada pada nilai rata-rata 3.57 dengan kriteria jawaban kuat, untuk meningkatkannya perusahaan harus memberikan kesenangan dan kenyamanan yang dibutuhkan para karyawannya agar karyawan tersebut tetap serius menjalankan dan menyelesaikan pekerjaannya dan tetap berperilaku baik dalam bekerja

Untuk dimensi filosofi dalam indikator penghormatan sesama karyawan pada nilai rata-rata 3,54 dengan kriteria jawaban kuat, ha ini bisa ditingkatkan dengan cara membuat kerja sama tim sehingga dengan cara itu karyawan semakin sering bersosialisasi dan saling menghargai satu sama lain.

Lalu pada dimensi aturan dalam indikator pemberlakuan sanksi pada nilai rata-rata 3,31 dengan kriteria jawaban cukup kuat, cara mengatasi hal ini dengan cara mempertegas aturan-aturan dalam perusahaan dan memberikan sanksi langsung ke karyawan yang telah dan melakukan kesalahan sehingga tidak terjadi lagi kesalahan-kesalahan dalam penyelesaian tugas. Untuk dimensi iklim organisasi dalam indikator kenyamanan suasana perusahaan pada nilai rata-rata 3,57 dengan kriteria jawaban kuat, dalam hal ini cara meningkatkannya yaitu perusahaan perlu menciptakan ruang kerja yang lebih nyaman dengan mengatur tata letak ruangan dengan baik serta menambah jumlah tenaga kerja cleaning service agar kebersihan ruangan tetap terjaga

\section{c. Kinerja Karyawan pada PT Bank Sumut Kantor Cabang Syariah Pematangsiantar}

Kinerja merupakan salah satu hal penting dalam penilaian perusahaan karena sangan menentukan keberhasilan suatu perusahaan. Pada kinerja karyawan, nilai keseluruhan ratarata sebesar 3,62 dengan kriteria jawaban baik. Namun ternyata ada beberapa indikator yang perlu diperhatikan karena nilainya masih di bawah rata-rata, seperti pada dimensi prestasi kerja dengan indikator tanggung jawab dalam menyelesaikan tugas diperoleh nilai rata-rata 3,11 dengan kriteria jawaban cukup baik, cara meningkatkannya pemimpin harus lebih tegas atas tugas yang diberikan untuk karyawannya, sehingga karyawan dapat mengerjakan tugas dengan sungguh-sungguh.

Pada dimensi perilaku kerja, dengan indikator mempertahankan integritas dalam bekerja diperoleh nilai rata-rata 3,14 dengan kriteria jawaban cukup baik, cara meningkatkannya karyawan sebaiknya memahami semua prosedur yang berlaku diperusahaan agar tugas yang dilaksanakan sesuai dengan prosedur perusahaan.

Dalam hal ini dapat dilihat bahwa kinerja karyawan pada PT Bank Sumut Kantor Cabang Syariah Pematangsiantar sudah dikategorikan baik. Walaupun sudah dikategorikan baik, namun karyawan sebaiknya lebih tekun dan gigih dalam bekerja untuk mencapai kinerja yang maksimal.

\section{KESIMPULAN DAN SARAN}

\section{Kesimpulan}

a. Hasil analisis deskriptif kualitatif tentang gaya kepemimpinan memiliki nilai rata-rata sebesar 3,78 yang berkriteria jawaban baik. Nilai jawaban responden tertinggi ada pada dimensi gaya kepemimpinan otokratis untuk indikator pembatasan partisipasi karyawan sebesar 4,14 berkriteria jawaban baik dan nilai jawaban responden terendah berada pada dimensi gaya kepemimpinan otokratis untuk indikator metode kerja yang didikte pimpinan sebesar 3,17 dengan kriteria jawaban cukup baik.

b. Hasil analisis deskriptif kualitatif tentang budaya organisasi diperoleh nilai rata-rata sebesar 3,64 dengan kriteria jawaban kuat. Nilai rata-rata yang tertinggi sebesar 3,94 dengan kriteria jawaban kuat berada pada dimensi nilai dominan untuk indikator standar efisiensi kinerja. Sedangkan nilai rata-rata terendah sebesar 3,31 dengan kriteria jawaban cukup kuat berada pada dimensi aturan untuk indikator pemberlakuan sanksi saat melanggar tata tertib perusahaan.

c. Hasil analisis deskriptif kualitatif tentang kinerja karyawan diperoleh nilai rata-rata sebesar 3,63 dengan kriteria jawaban baik. Kemudian nilai rata-rata tertinggi sebesar 4,08 dengan kriteria jawaban baik berada pada dimensi perilaku kerja untuk indikator kemampuan anda bekerja secara optimal sepanjang jam kerja. Sedangkan nilai ratarata terendah sebesar 3,11 dengan kriteria jawaban cukup baik berada pada dimensi prestasi kerja untuk indikator tanggung jawab.

d. Hasil analisis regresi linier berganda diperoleh nilai $\hat{Y}=7,323+0,518 X_{1}+0,173$ 
$X_{2}$, artinya terdapat pengaruh yang positif antara gaya kepemimpinan $\left(X_{1}\right)$ dan budaya organisasi $\left(X_{2}\right)$ terhadap kinerja karyawan (Y) pada PT Bank Sumut Kantor Cabang Syariah Pematangsiantar.

e. Hasil analisis korelasi diperoleh nilai $r=$ 0,831 yang artinya terdapat hubungan yang sangat kuat dan positif antara gaya kepemimpinan dan budaya organisasi dengan kinerja karyawan PT Bank Sumut Kantor Cabang Syariah Pematangsiantar. Selanjutnya diperoleh koefisien determinasi R sebesar 0,691 artinya baik tidaknya kinerja karyawan sebesar $69,1 \%$ dijelaskan oleh gaya kepemimpinan dan budaya organisasi dan selebihnya 30,9\% dipengaruhi oleh faktor lain seperti kompetensi karyawan, pengembangan karir, kompensasi, kepuasan kerja, dan kemampuan intelektual.

f. Hasil pengujian hipotesis secara simultan dengan uji $F$, terdapat pengaruh yang positif dan signifikan antara variabel gaya kepemimpinan dan budaya organisasi terhadap kinerja karyawan, dibuktikan dengan nilai $F_{\text {hitung }}$ sebesar $35,771>F_{\text {tabel }}$ $(0,05 ; 2$ VS 32) sebesar 3,29 atau dengan taraf signifikansi $0,000<\alpha 0,05$.

g. Hasil pengujian hipotesis secara parsial dengan uji $t$, diperoleh nilai thitung pada variabel Gaya Kepemimpinan $\left(X_{1}\right)$ sebesar $3,704>t_{\text {tabel }}$ dengan $\mathrm{df}=\mathrm{n}-\mathrm{k}-1(35-2-1=32)$ sebesar 2,036, atau dengan taraf signifikan $0,001<\alpha 0,05$, maka $\mathrm{H}_{0}$ ditolak, artinya terdapat pengaruh yang positif dan signifikan antara variabel gaya kepemimpinan dan budaya organisasi terhadap kinerja karyawan. Sedangkan $t_{\text {hitung }}$ pada variabel budaya organisasi $\left(X_{2}\right)$ sebesar 2,612 $>t_{\text {tabe }}$ dengan $\mathrm{df}=\mathrm{n}-\mathrm{k}-1 \quad(35-2-1=32)$ sebesar 2,036, atau dengan taraf signifikansi 0,014 < $\alpha 0,05$, maka $\mathrm{H}_{0}$ ditolak, artinya budaya organisasi berpengaruh positif dan signifikan terhadap kinerja karyawan pada kantor PT Bank Sumut Kantor Cabang Syariah Pematangsiantar secara parsial.

\section{Saran}

a. Untuk meningkatkan gaya kepemimpinan pada PT Bank Sumut Kantor Cabang Syariah Pematangsiantar, sebaiknya pimpinan/manajer kiranya memberikan metode maupun langkah kerja yang baik untuk para bawahannya dalam penentuan tugas lalu memberikan kesempatan kepada para karyawannya dalam pengambilan keputusan walaupun hanya dalam situasi dan kondisi tertentu.

b. Untuk memperkuat budaya organisasi pada PT Bank Sumut Kantor Cabang Syariah Pematangsiantar, maka perlu mempertegas aturan-aturan dalam perusahaan dan memberikan sanksi langsung ke karyawan yang telah dan melakukan kesalahan sehingga tidak terjadi lagi kesalahankesalahan dalam penyelesaian tugas.

c. Untuk meningkatkan kinerja karyawan pada PT Bank Sumut Kantor Cabang Syariah Pematangsiantar, dengan cara karyawan harus lebih bertanggung jawab atas tugas yang diberikan, dan mengerjakan tugas dengan sungguh-sungguh lalu karyawan juga harus memahami semua prosedur yang berlaku diperusahaan agar tugas yang dilaksanakan sesuai dengan prosedur perusahaan.

\section{E. DAFTAR PUSTAKA}

Daft, Richard L. 2002. Manajemen. Jilid 1. Jakarta: Penerbit Erlangga.

Griffin, Ricky W. 2004. Manajemen. Cetakan Keempat. Jakarta: Penerbit Erlangga.

Handoko, T Hani . 2003. Manajemen. Yogyakarta: BPFE.

Handoko, T. Hani. 2004. Manajemen Sumber Daya Manusia. Jakarta: Erlangga.

Kreitner, Robert. 2014. Perilaku Organisasi (Organizational Behavior). Edisi Kesembilan. Jakarta: Salemba Empat.

Luthans. Fred. 2006. Perilaku Organisasi. Edisi Kesepuluh. Jakarta: Penerbit Andi.

Mathis, Robert L. Dan John H. Jackson. 2006. Human Resource Management (Manajemen Sumber Daya Manusia). Edisi Kesepuluh. Jakarta: Salemba Empat.

Mondy, R Wayne. 2008. Manajemen Sumber Daya Manusia. Jilid 1, Edisi Kesepuluh. Jakarta: Erlangga.

Rivai, Veithzal dan Mulyadi Deddy. 2012. Kepemimpinan dan Perilaku Organisasi. Jakarta: Rajawali Pers.

Robbins, Stephen R dan Mary Coulter. 2010. Manajemen. Edisi Kesepuluh. Jilid 1. Jakarta: Penerbit Erlangga.

Surat Edaran Bank Indonesia No.15/4. INTERN tanggal 26 Februari 2013.

Sutrisno, Edy. 2010. Budaya Organisasi. Cetakan Pertama, Edisi Kesatu. Jakarta: Kencana Prenada Media Group.

Thoha, Mifta. 2003. Perilaku Organisasi. Edisi Pertama. Jakarta: PT Raja Grafindo Persada.

Zainal, Veithzal Rivai, et. al. 2015. Manajemen Sumber Daya Manusia untuk Perusahaan. Edisi Ketiga. Jakarta: Rajawali Pers. 